ҚАЗАҚСТАН РЕСПУБЛИКАСЫ

ҰЛТТЫҚ ҒЫЛЫМ АКАДЕМИЯСЫНЫН

АБАЙ АТЫНДАҒЫ ҚАЗАҚ ҰЛТТЫҚ

ПЕДАГОГИКАЛЫҚ УНИВЕРСИТЕТІНІҢ

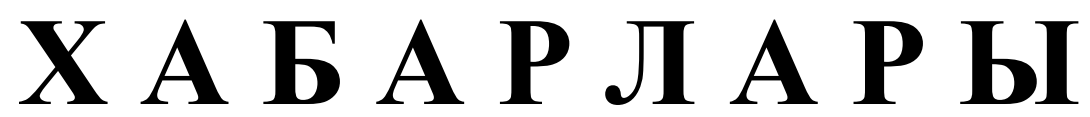

\section{ИЗВЕСТИЯ}

НАЦИОНАЛЬНОЙ АКАДЕМИИ НАУК РЕСПУБЛИКИ КАЗАХСТАН

КАЗАХСКИЙ НАЦИОНАЛЬНЫЙ

ПЕДАГОГИЧЕСКИЙ УНИВЕРСИТЕТ ИМ. АБАЯ

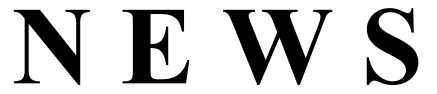

OF THE NATIONAL ACADEMY OF SCIENCES OF THE REPUBLIC OF KAZAKHSTAN

ABAY KAZAKH NATIONAL PEDAGOGICAL UNIVERSITY

ҚОҒАМДЫҚ ЖӘНЕ ГУМАНИТАРЛЫҚ ҒЫЛЫМДАР СЕРИЯСЫ

СЕРИЯ ОБЩЕСТВЕННЫХ И ГУМАНИТАРНЫХ НАУК

SERIES OF SOCIAL AND HUMAN SCIENCES

\author{
6 (322) \\ ҚАРАША - ЖЕЛТОҚСАН 2018 ж. \\ НОЯБРЬ - ДЕКАБРЬ 2018 Г. \\ NOVEMBER - DECEMBER 2018 \\ ИЗДАЕТСЯ С ЯНВАРЯ 1962 ГОДА \\ PUBLISHED SINCE JANUARY 1962 \\ ЖЫЛЫНА 6 РЕТ ШЫҒАДЫ \\ ВЫХОДИТ 6 РАЗ В ГОД \\ PUBLISHED 6 TIMES A YEAR
}

1962 ЖЫЛДЫҢ ҚАНТАР АЙЫНАН ШЫҒА БАСТАҒАН 
Ба с ре дактор

ҚР ҰҒА кұрметті мүшесі

Балықбаев Т.O.

Р е д а ц и я а лқ а сы:

экон. ғ. докторы, проф., ҚР ҰҒА академигі Баймұратов У.Б.; тарих ғ. докторы, проф., ҚР ҰҒА академигі Байпақов К.М.; филос. ғ.докторы, проф., ҚР ҰҒА академигі Есім Г.Е.; фил. ғ. докторы,, проф., ҚР ҰҒА академигі Қирабаев С.С.; эк. ғ. докторы, проф., ҚР ҰҒА академигі Кошанов А.К.; эк.ғ. докторы, проф., ҚР ҰҒА академигі Нәрібаев К.Н. (бас редактордың орынбасары); филос. ғ.докторы, проф., ҚР ҰҒА академигі Нысанбаев А.Н.; заң ғ. докторы, проф., ҚР ҰҒА академигі Сәбікенов С.Н.; заң ғ. докторы, проф., ҚР ҰҒА академигі Сүлейменов М.К.; эк. ғ. докторы, проф., ҚР ҰҒА академигі Сатыбалдин С.С.; тарих ғ. докторы, проф., ҚР ҰҒА академик Әбжанов Х.М.; тарих ғ. докторы, проф., ҚР ҰҒА корр. мүшесі Әбусеитова М.Х.; тарих ғ. докторы, проф., ҚР ҰҒА академик Байтанаев Б.А.; филол. ғ. докторы, проф., ҚР ҰҒА корр. мүшесі Жақып Б.А.; фил. ғ. докторы, проф., академик НАН РК Қалижанов У.К.; филол. ғ. докторы, проф., ҚР ҰҒА академик Қамзабекұлы Д.; тарих ғ. докторы, проф., ҚР ҰҒА академик Қожамжарова Д.П.; тарих ғ. докторы, проф., ҚР ҰҒА академик Койгелдиев М.К.; фил. ғ. докторы, проф., ҚР ҰҒА корр. мүшесі Кұрманбайұлы Ш.; тарих ғ. докторы, проф., ҚР ҰҒА корр. мүшесі Таймағанбетов Ж.К.; социол. ғ. докторы, проф., ҚР ҰҒА корр. мүшесі Шәукенова 3.К.; фил. ғ. докторы, проф., КР ҰҒА корр. мүшесі Дербісәлі А.; саяси. ғ. докторы, проф., Бижанов А.К., тарих ғ. докторы, проф., Кабульдинов 3.Е.; фил. ғ. докторы, проф., ҚР ҰҒА корр мүшесі Қажыбек Е.3.

\section{Р едакция ке н е с i:}

Молдова Республикасының ҰҒА академигі Белостечник Г. (Молдова); Әзірбайжан ҰҒА академигі Велиханлы Н. (Азербайджан); Тәжікстан ҰҒА академигі Назаров Т.Н. (Тәжікстан); Молдова Республикасының ҰҒА академигі Рошка А. (Молдова); Молдова Республикасының ҰҒА академигі Руснак Г. (Молдова); Әзірбайжан ҰҒА корр. мүшесі Мурадов Ш. (Әзірбайжан); Әзірбайжан ҰҒА корр. мүшесі Сафарова 3. (Әзірбайжан); э. ғ. д., проф. Василенко В.Н. (Украина); заң ғ. докт., проф. Устименко В.А. (Украина)

«Қазақстан Республикасы Ұлттық ғылым академиясының Хабарлары. Қоғамдық және гуманитарлық ғылымдар сериясы». ISSN 2224-5294

Меншіктенуші: «Қазақстан Республикасының Ұлттық ғылым академиясы» РҚБ (Алматы қ.)

Қазақстан республикасының Мәдениет пен ақпарат министрлігінің Ақпарат және мұрағат комитетінде 30.04.2010 ж. берілген № 10894-Ж мерзімдік басылым тіркеуіне қойылу туралы куәлік

Мерзімділігі: жылына 6 рет.

Тиражы: 500 дана.

Редакцияның мекенжайы: 050010, Алматы қ., Шевченко көш., 28, 219 бөл., 220, тел.: 272-13-19, 272-13-18, http://nauka-nanrk.kz. social-human.kz

(C) Қазақстан Республикасының Ұлттық ғылым академиясы, 2018

Типографияның мекенжайы: «Аруна» ЖК, Алматы қ., Муратбаева көш., 75. 
Главный редактор

Почетный член НАН РК

T.O. Балыкбаев

Р е дак ци онн а я коллег и я:

докт. экон. Н., проф., академик НАН РК У.Б. Баймуратов; докт. ист. н., проф., академик НАН РК К.М. Байпаков; докт. филос. Н., проф., академик НАН РК Г.Е. Есим; докт. фил. Н., проф., академик НАН РК С.С. Кирабаев; докт. экон. Н., проф., академик НАН РК А.К. Кошанов; докт. экон. Н., проф., академик НАН РК К.Н. Нарибаев (заместитель главного редактора); докт. филос. н., проф., академик НАН РК А.Н. Нысанбаев; докт. юр. Н., проф., академик НАН РК С.Н. Сабикенов; докт. юр. н., проф., академик НАН РК М.К. Сулейменов; докт. экон. Н., проф., академик НАН РК С.С. Сатубалдин; докт. ист. н., проф., академик НАН РК Х.М. Абжанов; докт. ист. н., проф., чл.-корр. НАН РК М.Х. Абусеитова; докт. ист. н., проф., академик НАН РК Б.А. Байтанаев; докт. фил. н., проф., чл.-корр. НАН РК Б.А. Жакып; докт. фиолол. н., проф., академик НАН РК У.К. Калижанов; докт. фил. н., проф., академик НАН РК Д. Камзабекулы; докт. ист. н., проф., академик НАН РК Д.П. Кожамжарова; докт. ист. н., проф., академик НАН РК М.К. Койгельдиев; докт. филол. н., проф., чл.-корр. НАН РК Ш. Курманбайулы; докт. ист. н., проф., чл.корр. НАН РК Ж.К. Таймаганбетов; докт. социол. н., проф., чл.-корр. НАН РК З.К. Шаукенова; д. филол. н., проф., чл.-корр. НАН РК А. Дербисали; доктор политических наук, проф., Бижанов А.К.; доктор ист. наук, проф., Кабульдинов 3.Е.; доктор филол. н., проф., член-корр. НАН РК Қажыбек Е.3.

Р е дак ци онны й с ов ет

академик НАН Республики Молдова Г. Белостечник (Молдова); академик НАН Азербайджанской Республики Н. Велиханлы (Азербайджан); академик НАН Республики Таджикистан Т.Н. Назаров (Таджикистан); академик НАН Республики Молдова А. Рошка (Молдова); академик НАН Республики Молдова Г. Руснак (Молдова); чл.-корр. НАН Азербайджанской Республики Ш. Мурадов (Азербайджан), член-корр. НАН Азербайджанской Республики 3.Сафарова (Азербайджан); д. э. н., проф. В.Н. Василенко (Украина); д.ю.н., проф. В.А. Устименко (Украина)

Известия Национальной академии наук Республики Казахстан. Серия общественных и гуманитарных наук. ISSN 2224-5294

Собственник: РОО «Национальная академия наук Республики Казахстан» (г. Алматы)

Свидетельство о постановке на учет периодического печатного издания в Комитете информации и архивов

Министерства культуры и информации Республики Казахстан № 10894-Ж, выданное 30.04.2010 г.

Периодичность 6 раз в год

Тираж: 500 экземпляров

Адрес редакции: 050010, г. Алматы, ул. Шевченко, 28, ком. 219, 220, тел. 272-13-19, 272-13-18, www:nauka-nanrk.kz / social-human.kz

(C) Национальная академия наук Республики Казахстан, 2018 г.

Адрес типографии: ИП «Аруна», г. Алматы, ул. Муратбаева, 75

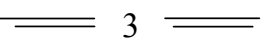


Chief Editor

\section{Honorary member of NAS RK \\ Balykbayev T.O}

Editorial board:

Doctor of economics, prof, academician of NAS RK Baimuratov U.B.; doctor of history, prof, academician of NAS RK Baipakov K.M.; doctor of philosophy, prof, academician of NAS RK Esim G.E.; doctor of philology, prof, academician of NAS RK Kirabayev S.S.; doctor of economics, prof, academician of NAS RK Koshanov A.K.; doctor of economics, prof, academician of NAS RK Naribayev K.N. (deputy editor-in-chief); doctor of philosophy, prof, academician of NAS RK Nyssanbayev A.N.; doctor of law, prof, academician of NAS RK Sabikenov S.N.; doctor of law, prof, academician of NAS RK Suleymenov M.K.; doctor of economy, prof, academician of NAS RK Satybaldin S.S.; doctor of history, prof, academician of NAS RK Abzhanov H.M; doctor of history, prof, corresponding member of NAS RK Abuseitova M.H.; doctor of history, prof, academician of NAS RK Baitanaev B.A.; doctor of philology, prof, corresponding member of NAS RK Zhakyp B.A.; doctor of philology, prof, academician of NAS RK Kalizhanov U.K.; doctor of philology, prof, academician of NAS RK Hamzabekuly D.; doctor of history, prof, academician of NAS RK Kozhamzharova D.P.; doctor of history, prof, academician of NAS RK Koigeldiev M.K.; doctor of philology, prof, corresponding member of NAS RK Kurmanbaiuly Sh.; doctor of history, prof, academician of NAS RK Taimaganbetov J.K.; doctor of sociology, prof, corresponding member of NAS RK Shaukenova Z.K.; doctor of philology, prof, corresponding member of NAS RK Derbisali A.; doctor of political science, prof Bizhanov A.K; doctor of History, prof Kabuldinov Z.E.; doctor of philology, prof, corresponding member of NAS RK Kazhybek E.Z.

\section{Editorial staff:}

Academician NAS Republic of Moldova Belostechnik.G (Moldova); Academician NAS Republic of Azerbaijan Velikhanli N. (Azerbaijan); Academician NAS Republic of Tajikistan Nazarov T.N. (Tajikistan); Academician NAS Republic of Moldova Roshka A. (Moldova) Academician NAS Republic of Moldova Rusnak G. (Moldova); Corresponding member of the NAS Republic of Azerbaijan Muradov Sh. (Azerbaijan); Corresponding member of the NAS Republic of Azerbaijan Safarova Z. (Azerbaijan); Associate professor of Economics Vasilenko V.N. (Ukraine), Associate professor of Law Ustimenko V.A. (Ukraine)

News of the National Academy of Sciences of the Republic of Kazakhstan. Series of Social and Humanities. ISSN 2224-5294

Owner: RPA "National Academy of Sciences of the Republic of Kazakhstan" (Almaty)

The certificate of registration of a periodic printed publication in the Committee of information and archives of the Ministry of culture and information of the Republic of Kazakhstan N 10894-Ж, issued 30.04.2010

Periodicity: 6 times a year

Circulation: 500 copies

Editorial address: 28, Shevchenko str., of. 219, 220, Almaty, 050010, tel. 272-13-19, 272-13-18, www:nauka-nanrk.kz / social-human.kz

(C) National Academy of Sciences of the Republic of Kazakhstan, 2018

Address of printing house: ST "Aruna", 75, Muratbayev str, Almaty 
N E W S

OF THE NATIONAL ACADEMY OF SCIENCES OF THE REPUBLIC OF KAZAKHSTAN

SERIES OF SOCIAL AND HUMAN SCIENCES

ISSN 2224-5294

https://doi.org/10.32014/2018.2224-5294.30

Volume 6, Number 322 (2018), 13 - 20

JEL343.132

\author{
Z.K.Ayupova ${ }^{1}$, D.U. Kussainov ${ }^{2,}$ Winston Nagan ${ }^{3}$ \\ ${ }^{1}$ Kazakh national agrarian university, Almaty, Kazakhstan; \\ ${ }^{2}$ Kazakh national pedagogical university named after Abai, Almaty, Kazakhstan; \\ ${ }^{3}$ University of Michigan, USA \\ zaure567@yandex.ru; daur958@mail.ru
}

\title{
SOME FACETS OF INTEGRATION IN THE MODERNIZATION OFTHE CIVIL PROCESS
}

\begin{abstract}
The rules of procedural law regulate the jurisdictional, i.e. law enforcement process, which is carried out in the form of law enforcement by specially authorized bodies (court, Prosecutor's office, police, etc.) in cases of crimes and other offenses or in disagreements, i.e. when the subjects of legal relations cannot come to an agreement on their rights and obligations and apply to the court. Procedural law can be defined as a set (system) of legal norms, governing the procedure, the form of jurisdictional law enforcement activities of the competent state bodies on officials, aimed at the implementation of the norms of various branches of substantive law. Law enforcement in procedural law is carried out with the assistance of law enforcement agencies. The activities of the state and its bodies cover many areas of state and public life. One of the central places in this implementation of the tasks, law and order in law-abiding state with the protection of human rights and freedoms, protection of the rights and interests of the state and non-governmental organizations, labor collectives, combating crimes and other offenses. The development of law-abiding stateis one of the main aims of our society.
\end{abstract}

Keywords: civil law, civil procedure, procedural norms, jurisdictional process, law enforcement process, integration, authorized body, sides agreement, mediation, mediator.

In order to provide appropriate advice, an expert advisory mediator should have substantial expertise in the subject matter of the dispute, knowledge of legal processes and outcomes and appropriate qualifications and experience. Mediators who have a background practicing law are particularly suited to the role of expert advisory mediator, where the evaluation is sought in relation to the law.

Expert advisory mediation may be appropriate when the parties want to negotiate in terms of rights, entitlements, credibility, merits or position. It may also be applied when it is clear that the parties only need an expeditious answer to a technically complex issue, and there are no issues of continuing relationships or psychological needs. All of these circumstances may be present in the court-connected context, where the dispute has been brought into an institution that applies legal principles, the disputants often place a high priority on their legal rights and entitlements, litigants may have no pre-existing relationship and want an efficient resolution of their dispute according to legal or commercial standards.

However, existing research has demonstrated that litigants often seek the satisfaction of non-legal interests through court-connected processes. Therefore, the context of litigation is an insufficient indicator of disputantse preferences for the narrow scope of expert advisory mediation.

In wise counsel mediation, the problem is defined more broadly than in expert advisory mediation. The focus is on a broader range of interests, and the mediator evaluates the case on the basis of those broadly defined legal and non-legal interests.

The primary aim of this kind of mediation is access to justice in the sense of a fair forum, efficient management of conflict and the pursuit of long-term, interest-based solutions. The mediator assumes some kind of responsibility for the options generated and the final agreement. 
Wise counsel mediation may be appropriate when the disputants want to explore a broader range of concerns than the narrow legal interests and want the mediator to provide some guidance about the resolution of the dispute. Court-connected mediators may practice this model of mediation.

This ancient kind of mediation is used in many traditional groups, including indigenous communities and religious groups. The primary aim of tradition-based mediation is to restore stability and harmony to the community, industry or group. These mediators are usually leaders, chiefs or elders who are trusted to guide the parties to a solution that is in accordance with community norms. Tradition-based mediation may be appropriate when parties are part of a professional, business of cultural community where group norms are more influential than legal norms.

The tradition-based model is clearly an alternative to mainstream dispute resolution options. Its applicability to the court-connected setting is therefore questionable. In mediation connected with specialist bodies, such as the Native Title Tribunal, it may be appropriate to conduct a tradition-based mediation. In this thesis it is assumed that tradition-based mediation would not be conducted in connection with a court. The standards that apply are, by definition, distinct from the legal standards that form at least a frame of reference in mediation connected with the formal civil justice system.

There is no clear theoretical framework for mediation in connection with courts. Consequently, there is scope for court-connected mediation to promote any of the theoretical purposes of mediation, including satisfaction of individual interests, equality between the parties or transformation. These purposes are likely to be tempered in the court-connected context, partly by the institutional preoccupation with efficiency. However, efficiency is unlikely to be pursued as the sole aim of a court connected program. In the court-connected context there will at least be some emphasis on the satisfaction of the parties' legal interests.

In the absence of clear and limiting guidelines, it is inappropriate to limit the consideration of courtconnected mediation to any one particular practice model, ideology or purpose. Although some definitions of mediation limit its breadth in particular contexts, court-connected programs typically apply broad and inclusive definitions of mediation rather than limiting definitions that confine practice to particular models. The opportunities to embrace a range of practice models are not generally restricted by legislation, policy or program specific guidelines. Further, no clear, limiting definition of how mediation ought to be applied to courts has been established anywhere in theory. Flexibility is preserved, notwithstanding tendencies in practice toward a narrow problem definition, focus on settlement and priority of legal issues.

Accordingly, core features of mediation which are universal throughout the field serve as the touchstone for the examination of court-connected mediation.

Even though conceptualizations and models of mediation display a rich diversity, some foundational attributes of mediation can nevertheless be identified that are universal in ideologies and constructs of mediation. The extent to which these core features are realized varies infinitely between theories, practices, participants, contexts, conflicts and skill sets. Nevertheless, they remain to some degree core components of all mediation practice models and all of the purposes that may be promoted through mediation ideologies. The core features that are common within the mediation field are: responsiveness to the individual disputants, self-determination and cooperation.

Responsiveness, self-determination and cooperation have been identified as underlying values of mediation. The idea that the people involved in a conflict will have some choice about their dispute resolution process and will have an opportunity to resolve their conflict in their own way is grounded in the value of responsiveness. The responsive capacity of mediation is derived from its inherent flexibility of both process and outcomes. Mediation provides opportunities for people in conflict to determine how they will participate in the dispute resolution process and to control the way that their conflict is resolved. The self-determinative capacity of mediation is derived from the opportunities for disputants to participate directly in the process, a degree of control over the process and ultimate responsibility for the outcome. Cooperation is essential to mediation, where people involved in conflict are provided with an opportunity and encouraged to cooperate with one another. The structures, processes and potential outcomes of mediation provide the cooperative opportunity, notwithstanding that participants cannot be forced to cooperate [1, P.54]. 
The core features of mediation and the key opportunities linked to each of them will serve as a touchstone for the examination of court-connected mediation practice in the Supreme Court of Kazakhstan. The connection with the court, the participation of lawyers, the influence of legal norms and the expectations of participants all impact on the nature of court-connected mediation practice. Nonetheless, it is still appropriate for each of the features to be present in the court-connected mediation context to some degree.

Responsiveness is about the tailoring of the mediation process and outcomes to meet the needs and preferences of the individual disputants. The degree to which the mediation process responds to individual circumstances will vary. However, the fundamental responsive feature of mediation is that there is an opportunity to respond to the individual disputants' interests and preferences regarding process or content in some way. In mediation there is no imposition of a strictly standard or pro- forma process to every case, except where there are program- specific limitations imposed. Nor is there an obligation to resolve disputes in accordance with strict legal entitlements. These features distinguish mediation from trial processes and are shared with negotiation. In mediation and negotiation, there may be norms that develop as to the "usual" way of conducting the process; however these norms may be departed from as appropriate. There is always some capacity to respond to the individual circumstances in mediation.

Responsiveness reflects the priority of individualism over collectivism that was a stimulus to the development of the modern mediation field. Individualism is highly prioritized in the satisfaction purpose but less of a priority in the equality or justice frameworks. In the facilitative model of the mediation process, the individual needs and interests of the parties are responded to. The settlement model responds to a perceived interest in efficiency and settlement. In the transformative context, responsiveness is focused on the relational interests of the individual participants[2, P.17].

The key opportunity that responsiveness presents is for the individual preferences of the participants to drive the mediation process and to influence the mediation outcomes. Responsiveness is delivered through the flexibility and informality of the mediation process and the availability of individualized outcomes. Two statements that express the theoretical construct of responsiveness in mediation are:

- Mediation is responsive to the process needs of disputants through its flexibility.

- Mediation provides an opportunity for the interests and preferences of the individual disputants regarding content to be explored and reflected in the outcome.

The mediation process is flexible because it can be adapted to suit the circumstances and needs of the individual participants. Possible variations include: regular breaks, the possibility of adjourning the process and reconvening at a future time, having the disputants physically in separate rooms, use of comediation, variations in the role of supporters such as legal practitioners or advocates, as well as variations in the style of negotiation that is facilitated.

The diversity inherent in mediation practice and the scope for a range of techniques to be adopted by mediators are factors that enable the process to be tailored to meet the needs or preferences promoted in individual cases. Thus, even in a mediation program where the "usual" practice is to conduct a positional bargaining styled settlement conference, a particular person may express a desire to have a different kind of dialogue that might satisfy non-monetary interests. Mediation is able to respond to such preferences. This is what sets mediation apart from more rigid and regulated processes such as arbitration, trial or pretrial settlement conferences presided over by a judge.

There may be some limitations to the degree of flexibility of the mediation process. For example, there may be time constraints imposed by the mediation service provider, inadequate facilities to accommodate separate rooms or guidelines that limit the roles of participants or that restrict the style of mediation. These vary between mediation programs. Although time constraints and the nature of facilities may impact on process responsiveness in court-connected mediation, there are usually no restrictions imposed about the style of mediation allowed to be practiced

Mediation potentially offers disputants great flexibility in the nature of the agreements that they make, which means that outcomes can be responsive to the particular needs and interests of the disputants. In mediation, disputants are not limited to the outcomes that would be awarded by a court. Disputants may choose to apply legal or other norms to the resolution of their dispute[3, P.58].

The legal framework may be acceptable, workable and preferable for many disputants. A defining feature of mediation is the ability to depart from those norms, depending upon the preferences of the 
individuals in dispute. Although the law may be highly influential, it won't necessarily determine the outcomes that disputants negotiate. Disputantsmay take into account business needs, non-financial considerations, the timing of payments and place value on an apology. Furthermore, disputants may choose to make "interim" arrangements that can be tested in the short term before a final agreement is negotiated.

There are virtually no limits to the nature of agreements that can be made at mediation, although agreements that are illegal or open to challenge on the basis of public policy are not legally enforceable.

The availability of a range of outcomes is a feature of all models of mediation. However, in mediation where there is reluctance to explore a broad range of issues, the range of options that are generated tends to be limited. Models of mediation that encourage a narrow definition of the problem include settlement and expert advisory mediation. Options are also limited where the process of option generation is not separated from the process of evaluating options. This separation is part ofinterest-based, facilitative styles of mediation. The key to the delivery of responsiveness is that disputants have some control over the scope of problem-definition that is applied to their mediation.

A primary means of responding to the individual preferences of the disputants about the scope of mediation is to ensure that their individual interests and preferences regarding content are discussed during the mediation.

This opens the way for them to form part of the discussion in mediation and to be responded to in some way. The individual preferences of the disputants might include having legal and non-legal interests considered or restricting the scope of the mediation to legal entitlements. Unless the parties have had an opportunity to convey their preferences about such matters, the mediation process cannot respond to them. Where the individual preferences of the disputants have not been voiced during mediation, it is doubtful that any outcome will reflect those preferences. A primary indicator of whether or not there has been an opportunity to express needs and preferences is whether or not disputants participated actively in the mediation process.

The capacity for mediation to produce responsive outcomes places it in direct contrast to the "limited remedial imagination" of the legal system, which is subject to strict guidelines about the types of (generally monetary) outcomes that a court can impose. Mediated outcomes can be contrasted with trial outcomes in two main respects; namely, that the decision makers are involved in the dispute and may apply subjective criteria in decision-making and that there is a focus on the future rather than the past. Courts are bound to apply the law uniformly to all disputes and have an obligation to treat all litigants equally. Mediation provides an opportunity for the disputants themselves to make decisions, free from any obligation to adhere to judicial decision-making boundaries. Courts have a retrospective focus and are limited to redress for past behaviors. By contrast, in mediation there is an opportunity to focus on the future and to tailor solutions that meet future needs and preferences[4, P.414].

The degree of responsiveness that is likely to be achieved in court-connected mediation is affected by the degree of informality, the prioritization of legal standards and difficulties associated with the departure from traditional notions of justice within a public institution of justice. Each of these factors is influenced by both the court-context and the participation of lawyers in the process.

An aspect of flexibility in the mediation process in court-connected settings is informality. The degree of informality of court-connected mediation varies according to subjective assessments of informality and the nature of the mediation program. Mediation is less formal than the trial and pre-trial court processes but is more formal than direct negotiation between disputants or their lawyers. Where it is perceived that court-connected mediation replaces formal court proceedings, it is clearly a less formal process than the one it replaces. The purpose of a process that is less formal than traditional court processes is to make disputants feel comfortable and to create an environment that is conducive to open negotiations.

Where court-connected mediation occurs on the court premises, it may have an air of authority that discourages participants from treating it as an informal process. This air of authority increases when the mediator is an officer of the court.

The presence of the mediator and the disputants means that court-connected mediation is generally more formal in nature than unassisted lawyer negotiation. Because lawyer negotiation has traditionally resolved the overwhelming majority of civil litigated matters, court-connected mediation may in fact replace a less formal process. Mediation is a more structured process than lawyer negotiation, offers the

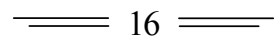


disputants an opportunity to participate directly and has the advantage that participant behavior can be monitored by the mediator. These features of mediation may be preferable to lawyer negotiation for some disputants.

The presence of "repeat player" professional participants also impacts on the formality of courtconnected mediation. Such participants include the mediator, lawyers and representatives of institutional parties. These people are comfortable and familiar with the court setting and the way the mediation process "usually" precedes. This may be daunting for other "one shot" participants who are less familiar and comfortable with the mediation environment. Participants who are unfamiliar with the process may not appreciate that they could exercise some influence over the manner in which it is conducted[5, P.17].

Despite theoretical constructs of mediation that celebrate its freedom from legal constraints, the law plays a significant and highly influential role in court-connected mediation. Court-connected mediation generally occurs within the litigation process, when the respective legal claims have been defined and where trial is not a distant possibility. When mediation occurs within these circumstances, it is said to take place in the "shadow of the law". The law is a relevant consideration in all dispute resolution, but is of particular influence in court-connected processes. When mediation occurs during the litigation process, a judicial decision is a realistic alternative to a negotiated settlement. Therefore, predictions about the legal outcome are a particularly important reference point for options generated in court-connected mediation.

The tendency for lawyers to adopt a narrow view of their clients' problems is problematic, because empirical evidence has shown that clients would prefer that a broader approach was adopted. For example, Relis concluded that the lawyers interviewed in her investigation into medical malpractice claims perceived that plaintiffs sued for a monetary settlement. On the other hand, the plaintiffs stressed that they did not sue for money, but for a host of non-legal reasons. The satisfaction of emotional or psychological needs of their clients was perceived to be a secondary or incidental mediation outcome by the lawyers $[6$, P.675].

When lawyers misunderstand their clients' preferences in this way, responsiveness is compromised. A possible solution is for disputants to be asked directly by the mediator about their reasons for mediating.

In court-connected mediation legal experts may outnumber the disputants, for example in a two party dispute where each party brings a lawyer to mediation and the mediator is also legally trained. If the legal participants are of the view that the law is the paramount consideration, it will be difficult for disputants to steer the content of discussions in other directions. This is particularly the case when lawyers adopt a spokesperson role and speak on behalf of their clients.

There is evidence of change within the legal profession, including a growing awareness of the benefits of addressing a broad range of clients' interests and more client-centered approaches to legal practice. Whatever their understanding of their clients' needs and preferences, lawyers are influential in determining the degree of responsiveness of court-connected mediation. Therefore, their perspectives are an important consideration in understanding court-connected mediation.

A third aspect of court-connected mediation that influences responsiveness is that some difficulty may arise if non-legally available outcomes are reached within the public institution of justice.Departing from the fundamental notion of substantive justice that underpins the adversary legal system may be problematic for courts. Inadequate monitoring of the mediation process may leave the court open to criticism that it is promoting settlement without adequate safeguards against unjust settlement outcomes. Conversely, court-connected mediation may be open to criticism if it restricts the options that are available to disputants or stifles their creativity. Clearly, from the mediation perspective it is problematic to apply objective legal standards rigidly to assess the appropriateness of outcomes that were developed in response to the individual needs of the disputants.

Views about the departure from legal norms in court-connected mediation are likely to vary depending upon whether court-connected mediation is seen as an alternative process or merely as a means of resolving litigation efficiently. The forces which detract from responsiveness in court-connected mediation decrease the likelihood that court-connected mediation will achieve the potential of reaching imaginative, tailor-made solutions through an individualized process. Instead they may promote the adoption of a pre-determined and formalized process and pursuit of outcomes that accord with objective notions of "fairness". Nonetheless, even if a "cookie-cutter" approach is adopted in ,usual" cases, there is some capacity to respond to individual disputants by adapting the process where necessary or desirable. 
The existence of a capacity to adapt to the individual disputants is a defining feature of mediation. This opportunity is expected in the court-connected context in the absence of restrictive directives about process characteristics.

A key indicator of responsiveness is that there is an opportunity extended to disputants to define the scope of the mediation conversation. That is, to express their interests and preferences about content and thereby shape the mediation process and outcomes accordingly. The degree to which this opportunity is extended to disputants in the Supreme Court of Kazakhstan by mediators and lawyers is examined in this thesis.

According to the National Mediation Practice Standards the purpose of a mediation process is to maximize participants' decision making. By participating in a meaningful way in the resolution of their own disputes, it is perceived that disputants can take responsibility for their own disputes and retain their dignity. The consequences of self-determination are that the disputants are empowered and given responsibility for the choices that they make in relation to their dispute. Empowerment is often considered to be an essential characteristic of mediation.

Self-determination sets mediation apart from determinative processes such as arbitration and judicial decision making. In those processes, other people decide both how the dispute should be resolved and what the outcome will be. The role of the disputant in determinative processes is to persuade the third party decision-maker to make decisions in accordance with that disputant's wishes. This persuasion is usually conducted by a lawyer. The disputants compete with one another to persuade the decision-maker. They have minimal control over either the process or the outcome.

Self-determination reflects the notion that mediation is about the disputants themselves deciding how to deal with their dispute, both in terms of process and outcomes. Two statements that reflect the theoretical construct of self-determination are:

- Mediation provides an opportunity for disputants to participate directly in the resolution of their dispute.

- In mediation, the disputants themselves decide how their dispute will be resolved.

In transformative mediation, the process and outcomes are self-determined. In facilitative mediation, the mediator may intervene to manage the process but will endeavor to facilitate outcomes determined by the parties. In settlement mediation, the process may be more pre-determined but there will still be some degree of voice and choice as to how the process is conducted and what information is shared. In the evaluative models, it is expected that legal or other expert issues will form part of the conversation, but it is not necessarily limited to them. In all practice models, there is some element of self-determination in the way the dispute is resolved. A particular model may be adopted because it suits the individuals involved, rather than being imposed upon them.

The degree of control that disputants have over the mediation process varies considerably in mediation practice. Some mediators facilitate preliminary negotiations about the way the mediation will be conducted. However, disputant control is limited because most mediators are active in deciding the way that the mediation will be conducted.

Facilitative mediators are mediation and problem-solving experts whose main role is to facilitate a particular type of dispute resolution process. They steer discussions, interpret issues and guide the process. One of their tasks is to educate the disputants about problem-solving approaches to dispute resolution. The purpose of that task is to empower the disputants to better manage conflict, without the assistance of a mediator. In other words, although the facilitative mediator may be directive about the process of resolving the immediate dispute, the disputants may learn new skills that empower them to be more selfdetermining in the future.

By contrast, in transformative mediation processes, the mediator will be guided by the process preferences expressed by the clients[7, P.64].

Direct disputant participation promotes the disputant-centered nature of mediation and is a fundamental precursor to self-determination. Research findings have identified consistently that disputants value an opportunity to participate directly in mediation. For example, David P. MacKinnon has confirmed procedural justice assertions that mediating parties value a dignified, thorough and even-handed process, which provides them with an opportunity to speak and an assurance that they have been heard and understood. Sourdin's recent study of the Supreme and County Courts of Europe demonstrated that 59\% 
of the disputants surveyed in those jurisdictions (65\% of plaintiffs and $47 \%$ of defendants) would have liked to participate more in their mediation[6, P.677].

The benefit of direct disputant participation is that disputants are encouraged to talk and negotiate directly with each other to identify their own interests, consider options and assess outcomes.Disputants who participate actively in mediation have an opportunity to maximize the satisfaction of their individual needs as contrasted with those who take a passive role. Active participants contribute to the setting of the agenda for discussion and can ensure that it includes all of the issues they want raised. The interests that they have expressed can be considered in the formulation and consideration of options for resolution. On the other hand, without direct input from the disputants, the likelihood that the conversation will be about external rules or expectations rather than individual interests is heightened, because the participants.

In the conclusion we would like to remind, that some mediators seek to minimize reliance on professional assistance by insisting on direct disputant participation and an advisory as opposed to advocacy role for professionals. There are a number of problems with the expectation that all disputants will participate directly in mediation. The promotion of direct disputant participation without qualification ignores questions about whether particular individuals have the capacity to participate directly, whether it is appropriate that they do and whether they want to. Some disputants may not have the communication skills or the intellectual or emotional capacity to present their own interests properly in mediation. Sometimes the relationship between the disputants may be such that there is a power imbalance that may be exacerbated if the disputants negotiate directly with one another during the mediation process. Where disputants have engaged legal representation, they may prefer that their lawyers promote their interests on their behalf. Although self-determination may theoretically promote disputant responsibility, some disputants may prefer not to take responsibility for the resolution of their dispute. Where it is inappropriate or undesirable for disputants to participate directly, their interests may be communicated by another person such as an advocate or legal practitioner. The extent to which the disputants contribute to the mediation process then becomes dependent upon the nature of the relationship between the professionals and their clients. The style of representation adopted by legal practitioners who speak for their clients in mediation varies, depending upon their view of the self-determinative potential of mediation and the importance of their clients' subjective interests as opposed to their legal interests.

\section{REFERENCES}

[1] Nosyreva.E.I. Alternative dispute resolution in the United States.- Monograph. M.: OAO «PublishingHouse «Gorodets». 2005. 257 p. (inRus.).

[2] Lukianovskaya.O.V., Melnichenko R.G. Basics of legal conflictology and mediation. M.:FGOUVPOVAGS. 2011. 313 c. (in Rus.).

[3] DavidenkoD.L. Conciliatory procedures in the European legal tradition. M.:Infotropic, 2013. 259 p. (in Rus.).

[4] Na Luo, Ken Hyland. Intervention and Revision: Expertise and Interaction in Text Mediation // Sage Journal. 2017. Vol.34. Issue 4. P.414-440 https://doi.org/10.1177/0741088317722944(in English).

[5] Ayupova Z.K., Kussainov D.U. Ethnopolitical processes in the country and their reflection in the assemblyof people in Kazakhstan // ИзвестияНАНРК. 2018. № 1. С.17-21.https://doi.org/10.32014/2018.2224-5294(in English).

[6] David P. MacKinnon. Integrating Mediators and Moderators in Research Design // Sage Jornal. 2011. Vol.21. Issue 6. P.675-681 https://doi.org/10.1177/1049731511414148(in English).

[7] Robert U.Nagel and Govinda Clayton. Mediation and Foreign Policy // Politics. 2017. Vol. 7 Issue 1. P.64-78 https://doi.org/10.1093/acrefore/9780190228637.013.447(in English).

\section{3.К. Аюпова, Д.Ө. Кұсайынов}

\section{АЗАМАТТЫК ПРОЦЕССТЕРДІ ЖЕТІЛДІРУДЕГІ ИНТЕГРАЦИЯНЫН КЕЙБІР КЫРЛАРЫ}

Аннотация. Процессуалды құқық нормалары заңнамалық, яғни құқық қорғау процессіне ықпалын тігизеді, олар өз тарапынан құқықты қолдану формасы ретінде арнайы өкілетті органдар (сот, прокуратура, полиция т.б.) мекемелеріне тікелей ықпал етіп олардың іс-әрекеттерін белгілеп отырады. Егер де қылмыс жасалған жағдайларда немесе басқада заң бұзушылық болғанда, келісімге келеалмаған жағдайларда өздерінің құқықтарын қорғау үшін азаматтар сотқа жүгінеді. Процессуалды құқық деп осы жағдайларда қолданылатын құқықтық нормалармен тәртіпті жүзеге асыратын ережелерді айтамыз. Олар құқықты қолдану юрисдикциясы формаларын өкілетті мемлекетік органдар мен қызметкерлердің құқықты жүзеге асырудағы 
өкілеттіліктерін белгілеп береді. Құқықты қолдану іс-әрекеті процессуалды құқықта құқық қорғау органдары арқылы жүзеге асырылады. Мемлекеттің және оның белгілі лауазымды қызметкерлерінің іс-әрекеттері қоғамдық және мемлекеттік өмірдің көптеген қырларын қамтиды. Бұл бағыттағы мемлекет қызметінің негізінде құқықтық тәртіппен заңдылықты, адамдардың құқықтары мен еркіндіктерін қорғау, мемлекет мүддесін және мемлекеттік емес мекемелердің, еңбек ұжымдарының құқығын қорғап, қылмысқа қарсы күресуді құқық бұзуды тоқтатуды жүзеге асыру болып табылады. Құқықтық тәртіпті және заңдылықты жүзеге асыру ісімен мемлекеттің арнайы қызмет органдары шұғылданады.

Түйін сөздер: азаматтық құқық, азаматтық процесс, процессуалдық нормалар, юридикалық процесс , құқық қорғау процессі, интеграция, өкілетті орган, тараптардың келісуі, медиация, медиатор.

УДК 343.132

\author{
3.К.Аюпова ${ }^{1}$, Д.У. Кусаинов ${ }^{2,}$ Уинстон Наган ${ }^{3}$ \\ ${ }^{1}$ КазНАУ, кафедра права, г. Алматы, Республика Казахстан; \\ ${ }^{2}$ КазНПУим.Абая, общеуниверситетская кафедра политологии \\ и социально-философских дисциплин, г. Алматы, Республика Казахстан; \\ ${ }^{3}$ Университет Мичиган, США

\section{НЕКОТОРЫЕ ГРАНИ ИНТЕГРАЦИИ В СОВЕРШЕНСТВОВАНИИ ГРАЖДАНСКОГО ПРОЦЕССА}

Аннотация. Нормы процессуального права регламентируют юрисдикционный, т.е. правоохранительный процесс, который осуществляется в правоприменительной форме специально управомоченными органами (судом, прокуратурой, полицией и др.) в случаях совершения преступлений и других правонарушений или в разногласиях, т.е. когда субъекты правоотношения не могут прийти к соглашению по поводу своих прав и обязанностей и обращаются в суд.Процессуальное право можно определить как совокупность (систему) правовых норм, регламентирующих порядок, форму юрисдикционной правоприменительной деятельности компетентных государственных органов о должностных лицах, направленной на реализацию норм различных отраслей материального права.Правоприменительная деятельность в процессуальном праве осуществляется с помощью правоохранительных органов. Деятельность государства и его органов охватывает многие сферы государственной и общественной жизни. Одно из центральных мест в ней занимает выполнение задач по обеспечению правопорядка и законности, защите прав и свобод человека, охране прав и законных интересов государственных и негосударственных организаций, трудовых коллективов, борьбе с преступлениями и иными правонарушениями. Обеспечением правопорядка и законности специально занимается значительно меньший круг органов, те, которые существуют только или главным образом для выполнения такой роли.

Ключевые слова: гражданское право,гражданский процесс, процессуальные нормы,юрисдикционный процесс, правоохранительный процесс, интеграция, управомоченный орган,соглашение сторон, медиация, медиатор.

Information about authors: Almaty;

Ayupova Z.K. - doctor of juridical sciences, professor, chair of law, Kazakh national agrarian university, Kazakhstan,

Kussainov D.U. - doctor of philosophy sciences, professor, interuniversity chair of politology and socio-philosophy disciplines, Kazakh national pedagogical university named after Abai, Kazakhstan, Almaty;

Winston Nagan - Professor of law, University of Michigan, USA, Department of Law, United States of America. 


\section{МАЗМҰНЫ}

Беспаева Р.С., Бугубаева Р.О., Мануэль Ф. Грела2. Көрсеткіштердің теңдестірілген жүйесі негізінде Щучинск-Бурабай курорттық аймағын дамытудың кешенді стратегиясын қалыптастыру ................................................................................ 5

Аюпова 3.К., Құсайынов Д.Ө.Азаматтық процесстерді жетілдірудегі интеграцияның кейбір қырлары...................... 13

Құсайынова А. А., Вальдемар Козловски, Геращенко И. П.Қазақстан республикасындағы міндетті әлеуметтік сақтандырудың қаржылық-құқықтық тетіктерінің ерекшеліктері.

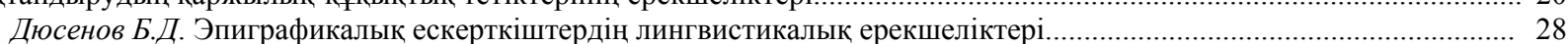

Джумадилова Ш.Г., Атабай Б.Ж. Қазақстандағы халықтың жинақтарының динамикасы......................................... 33

Карабалина А.А., Альситова А. Б., Кереймаганбетова Ж.Н., Абишева Н. М. Құндылық - рухани-адамгершілік

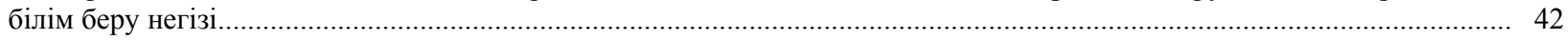

Кенжебаева Д.К., Өрмөрза Б. Ғ., Дашгин Махаммадли. Қазақстандық заманауи жастардың құндылығы............. 51

Нурманова А.Ш., Медерова Д.Е., Дюсенов Б.Д. «Бөкейхан әулетінің талдыбейіт қорымы» эпиграфикалық ескерткіштері тарихи дереккөз ретінде.

Кыдырова Ж.Ш., Онласынов Е.З., Абишова А.У., Шадиева А.А. Оңтүстік Қазақстан облысы сүт және сүт өнімдері нарығындағы жағдайды зерттеу ......

Абимова Г.У., Аманжолов Р., Мынбаева Б.Н., Ибрагимова Д.И. ЖОО-да биолог-студенттердің жобаларды

ұйымдастырылуы мен орындалуына даярлығы.......

Балтабаева А.Ю., Ризаходжаева Г. Мәдени интеграция үдерісіндегі жібек жолының феномені............................... 9

Бурганова Р.И., Абдугалина С.Е., Туякова А.Е. Студенттерге бағытталған білім беру арқылы білім сапасын

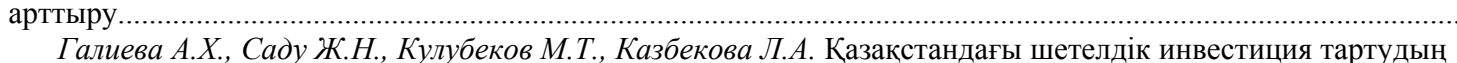

институционалдық жағдайын (талаптарын) бағалау..

Джалилов 3.Г., Батырхан Б.Ш. ХX ғ. екінші жартысындағы шетелдік исламтанушылардың ислам және саясат

туралы теориялық дискурсы.......

Джумабекова А.Т., Канатова А.Ж. Қаржылық ынтымақтастық жағдайларындағы Қазақстан республикасының

ұлттық банкінің өткізу механизмінің өзгеруі......

Дүйсен Г. М., Айтжанова Д. А. Қазақстан және Орталық Азия елдеріндегі көші-қон процесстері дамуының мәселелері мен ерекшеліктері

Есендұлова М.Н. Қазақстандағы « Қиын балаларды» оңалтудың және әлеуметтендірудің психологиялық ерекшеліктері

Жакишева К.М., Жуманова Д.Т., Мукашева Г.М. Экономиканың аграрлық секторының тұрақты дамуына арналған ауыл шаруашылық кәсіпорындарының қаржылық шарттарын мониторингінің рөлі.....

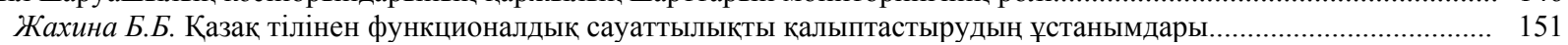

Идресова У.Х., Садуахасова 3.Ж., Муханова А.Т. Криминалистика....................................................................... 156

Савельева В. В. Қазақстандағы кредит технологиясын пайдалану және дамуының тарихи және педагогикалық базасы.

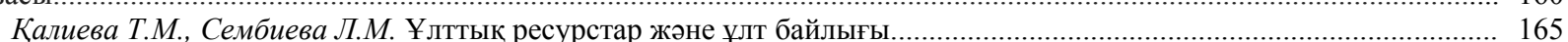

Каримова Р.У., Хаджиева Г.У. ҚХР Ұлттық саясаты контексіндегі ШҰАА-ның этносаяси және әлеуметтікэкономикалық трансформациясы мәселесі.

Керімбек Г., Молдашбаева Л., Джрауова Қ., Ажмухамедова А., Мизанова А. Қазақстан республикасының

республикалық бюджетіне түсетін салық түсімдерінің көрсеткіштерін талдау және бағалау.....

Жолдасбекова С.А., Парманкулова П.Ж., Асаналиев М.К. Мүмкіндігі шектеулі балаларды дамытудағы ұлттық ойындар

Молдакенова Е.К., Байгабулова К.К., Онаева Б.Т. БҚО-да инновациялық үрдістерді басқарудың аймақтық

аспектілігі жүйесінің дамудың жолдары.

Мұратова Г.К., Шаушенова А.Г., Жумасеитова С.Д., Онұварбаева М.Б.Білім беру үрдісінде бұлттық

технологияларын қолдану......

Несіпбеков E. Н., Аппакова Г.Н. Кәсіпорынның инвестициялық портфелін қалыптастырудың теориялық

Нургабылов М.Н., Барлыков Е.К., Егембердиева С.М. ҚР есеп өнеркәсібінің дамуының басқаруының трендсі....... 220

Нурымбетов Т.Я., Абишова А.У., Уразбаева Г.Ж., Кыдырова Ж.Ш., Байнеева П.Т., Абишо Н.У. Модернизациялық

жағдайындағы қр халқын әлеуметтік қолдауының басымдықтары.....

Рахимова С. А., Тургумбекова М. М. Қазақстан республикасындағы шағын және орта бизнестіңмемлекеттік қолдау

бағдарламалары және олардың тиімділігін жүзеге асыру шаралары.......................................................................... 233

Руденко Е.И. Орталық пен Оңтүстік Азия мемлекеттері арасындағы ұғынудың бұрмалануы - «Жұмсақ күш»

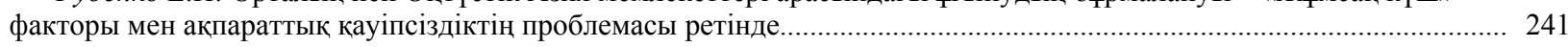

Тохтабаева Ш. Қазына-сандық.......................................................................................................... 251

Утепкалиева К.М., Сабирова Р.К., Кенбаева Г.У. Мұнай-газ секторындағы мемлекеттік-жеке серіктестікті дамыту

Мыңбаев Д. Е. Банкте басқару есебін ұйымдастыру тұжырымдамасы...

Султанова Г.С. Жаңа формацияның экономисі - бакалаврдың кәсіби құзыреттілігін қалыптастырудың

Шаяхметова А.А. Университет жағдайында инклюзивті білім беру үшін педагогтарды оқыту....... 


\section{СОДЕРЖАНИЕ}

Беспаева Р.С., Бугубаев Р.О., Мануэль Ф. Грела. Формирование комплексной стратегии развития ЩучинскоБоровской курортной зоны на основе сбалансированной системы показателей. Аюпова 3.К., Кусаинов Д.У., Уинстон Наган. Некоторые грани интеграции в совершенствовании гражданского процесса.

Кусаинова А.А., Козловски Вальдемар, Геращенко И.П. Обзор некоторых особенностей финансово-правового механизма обязательного социального страхования в республике Казахстан......

Дюсенов Б.Д. Лингвистические особенности эпиграфических памятников.............................................................. 28

Джумадилова Ш.Г., Атабай Б.Ж.Динамика сбережений населения в Казахстане................................................... 33

Карабалина А.А., Альситова А. Б., Кереймаганбетова Ж.Н., Абишева Н. М. Ценность как базовая основа духовнонравственного образования.

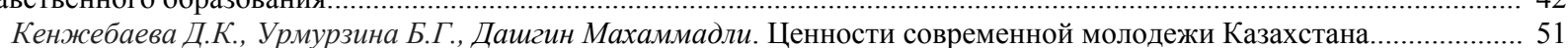

Нурманова А.Ш., Медерова Д.Е., Дюсенов Б.Д. Эпиграфические памятники «Некрополи талдыбейит династии

Бокейхановых» как исторический источник.

Кыдырова Ж.Ш., Онласынов Е.З., Абишова А.У., Шадиева А.А.Исследование ситуации на рынке молока и молочной продукции южно-казахстанской области

Абишова Г.У., Аманжолов Р., Мынбаева Б.Н., Ибрагимова Д.И. Готовность студентов-биологов к организации

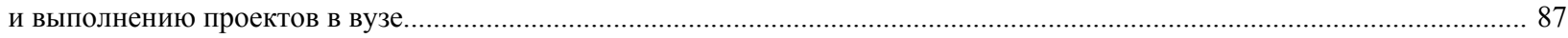

Балтабаева А.Ю., Ризаходжаева Г. Феномен великого шелкового пути в процессе культурной интеграции............... 91

Бурганова Р.И., Абдугалина С.Е., Туякова А.Е. Повышение качества образования посредством

студентоцентрированного обучения...

Галиева А.Х., Саду Ж.Н., Кулубеков М.Т., Казбекова Л.А. Оценка институциональных условий привлечения

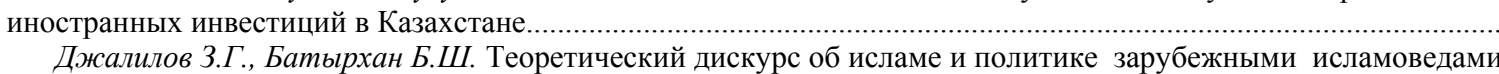
второй половины ХX в.

Джумабекова А.Т., Канатова А.Ж. Трансформация трансмиссионного механизма национального банка республики

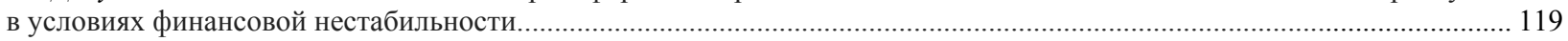

Дуйсен Г.М., Айтжанова Д.А. Проблемы и особенности развития миграционных процессов в Казахстане

и странах Центральной Азии.

Есенгулова М.Н. Психологические особенности реабилитации и социализации "Трудных подростков"

в Казахстане".

Жакишева К.М., Жуманова Д.Т., Мукашева Г.М.Роль мониторинга финансового состояния сельскохозяйственных

предприятий в обеспечении устойчивого развития аграрного сектора экономики..........................................................146

Жахина Б.Б. Принципы формирования функциональной грамотности казахского языка.......................................... 151

Идресова У.Х., Садуахасова 3.Ж., Муханова А.Т. Криминалистика......................................................................... 156

Савельева B.B. Исторические и педагогические основы формирования и разработки кредитной технологии

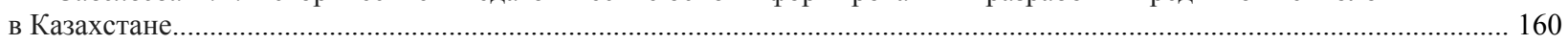

Калиева Т.М., Сембиева Л.М. Национальные ресурсы и богатство нации................................................... 165

Каримова Р.У., Хаджиева Г.У. К вопросу об этно-политической и социально-экономической трансформации

СУАР в контексте национальной политики КНР

Керимбек Г., Молдашбаева Л., Джрауова Қ., Ажмухамедова А., Мизанова А. Анализ и оценка показателей

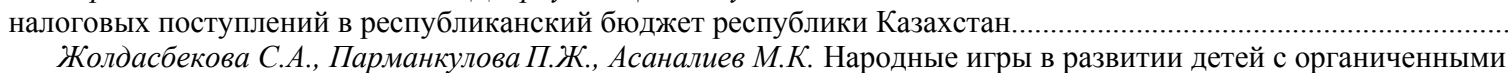

Жолдасбекова С.А., Парманкулова П.Ж., Асаналиев М.К. Народные игры в развитии детей с органиченными

Молдакенова Е.К., Байгабулова К.К., Онаева Б.Т.Пути развития системы регионального аспекта управления

инновационными процессами в АПК.

Муратова Г.К., Шаушенова А.Г., Жумасеитова С.Д., Онгарбаева М.Б. Применение облачных технологий

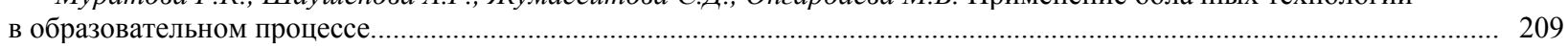

Несипбеков Е.Н., Аппакова Г.Н. Теоретические аспекты формирования инвестиционного портфеля предприятия. 214

Нургабылов М.Н., Барлыков Е.К., Егембердиева С.М. Тенденции управления развитием мясоперерабаты-

вающей отрасли в РК.

Нурымбетов Т.Я., Абишова А.У., Уразбаева Г.Ж., Кыдырова Ж.Ш., Байнеева П.Т., Абишов Н.У. Приоритеты

социальной поддержки населения РК в условиях модернизации................................................................................. 22

Рахимова С. А., Тургумбекова М. М. Программы государственной поддержки мсб в республике Казахстан и меры

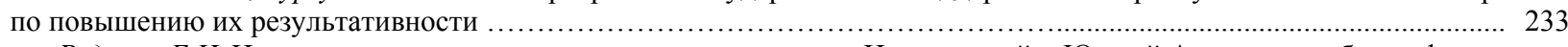

Руденко Е.И. Искаженность восприятия между государствами Центральной и Южной Азии как проблема фактора

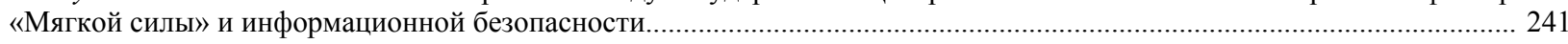

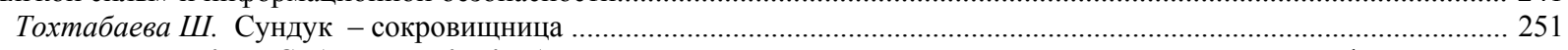

Утепкалиева К.М., Сабирова Р.К., Кенбаева Г.У.Развитие государственно-частного партнерства в нефтегазовой

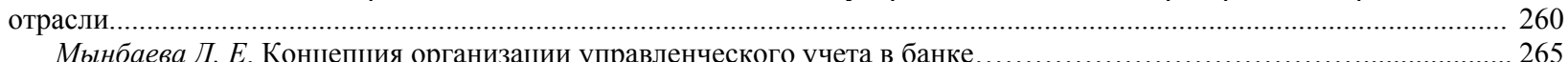

Мынбаева Д. Е. Концепция организации управленческого учета в банке...........................................2.
Султанова Г.С. Педагогические аспекты формирования профессиональных компетенций бакалавра - экономиста

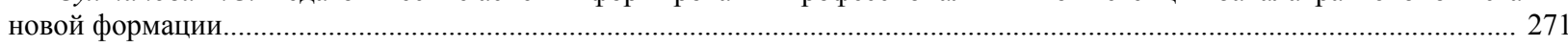

Шаяхметова А.А. О подготовке педагогических кадров к инклюзивному образованию в условиях вуза................ 277 


\section{CONTENTS}

Bespayeva R.S., Bugubayeva R.O., Manuel F. Grela. Formation of the complex strategy for development of the Schuchinsk-

Burabay resort area based on the balanced system of indicators.

Ayupova Z.K., Kussainov D.U., Winston Nagan. Some facets of integration in themodernization ofthe civil process..............13

Kussainova A.A., Kozlowski Waldemar, Gerashchenko I.P. The review of some features of the financial legal mechanism of obligatory social insurance in the republic of Kazakhstan...

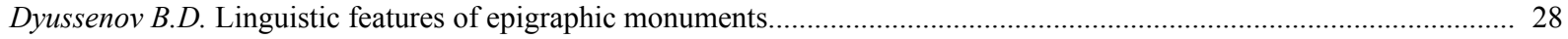

Jumadilova Sh.G., Atabay B.Zh. Dynamics of the population savings in Kazakhstan.......................................................... 33

Karabalina A.A., Alsitova A.B., Kereimaganbetova Zh.N., Abisheva N.M. The values as critical factor of moral education... 42

Kenzhebayeva D.K., Urmurzina B.G., Dashqin Mahammadli. The modern youth values in Kazakhstan............................. 51

Nurmanova A.S., Mederova D.E., Dyussenov B.D. "Bokeykhanov dynasty taldybeyit necropolis" epigraphic monuments

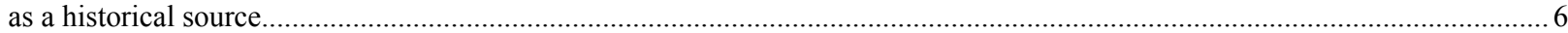

Kydyrova Zh.Sh., Onlasynov E.Z., Abishova A.U., Shadieva A.A.Research of the situation in the market of milk and dairy

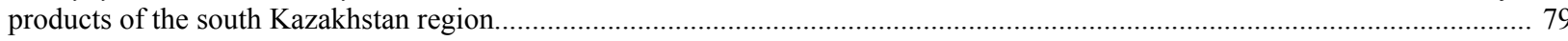

Abishova G.U., Amanzholov R.A., Mynbayeva B.N., Ibragimova D.I. Readiness of students-biologists for the organization

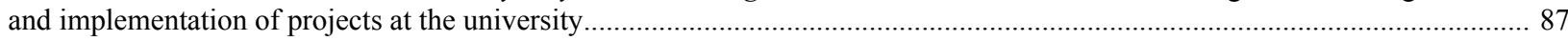

Baltabayeva A.Y., Rizakhojayeva $G$. The phenomenon of the great silk road in the cultural integration process................... 91

Burganova R.I., Abdugalina S.E., Tuyakova A.E. Improving the quality of education through student-centered education... 102

Galiyeva A.Kh., Sadu Zh.N., Kulubekov M.T., Kazbekova L.A. Assessment of the institutional terms of the foreign

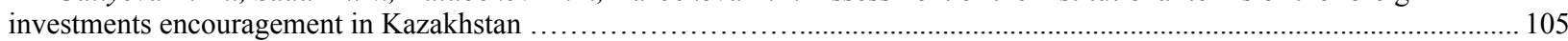

Dzhalilov Z.G. Theoretical discourse on islam and politics in foreign humanism of the second half of 20th century.......... 112

Dzhumabekova A.T., Kanatova A.ZH. Transformation of the transmission mechanism of the national bank of the republic

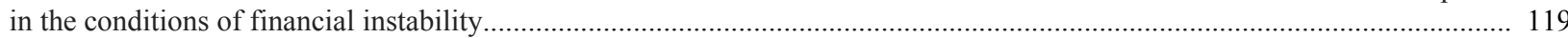

Suleimenov R.B. Problems and features of the development of migration processes in Kazakhstan and Central Asia.......... 124

Yesengulova M.N. Psychological aspects of reintegration and resocialization of "Trouble" adolescents in Kazakhstan....... 134

Zhakisheva K.M., Zhumanova D.T., Mukasheva G.M.The role of monitoring the financial condition of agricultural

enterprises in ensuring sustainable development of the agrarian sector of the economy............................................................146

Zhakhina B.B. Principles of functional literacy formation of the kazakh language....................................................... 151

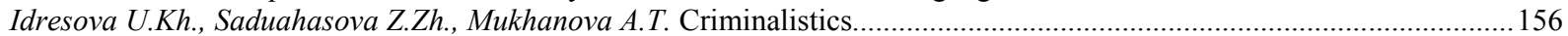

Savelyeva $V . V$. Historicalandpedagogical bases of formation and development of credit technology in Kazakhstan............ 160

Kaliyeva T.M., Sembiyeva L.M. National Resources and national wealth.................................................................. 165

Karimova R., Hajiyeva G. Examining ethno-political and SOCIO-economic transformation of the xinjiang uyghur

autonomous region in the context of the PRC national policies........................................................................................ 176

Kerimbek G., Moldashbayeva L., Jrauova K., Azhmukhamedova A., Misanova A. Analysis and evaluation of reduction

of tax recovery of the republic of kazakhstan on the budget of the republic of Kazakhstan................................................. 185

Zholdasbekova S.A., Parmankulova P.Zh., Assanaliyev M.K. Folk games in the education of children with physical, mental and sensory disturbances..

Moldakenova E.K., Baygabulova K.K., Onaeva B.T. Ways of development of the system of the regional aspect of managing innovative processes in the APC.

Muratova G.K., Shaushenova A.G., Zhumassseitova C.D., Ongarbayeva M.B. Application of cloud technologies in the educational process......

Nurgabylov M.N., Barlikov E.K., Egemberdieva S.M. Trends of management of the development of meat processing industry in RK

Nurymbetov T.Ya., Abishova A.U., Urazbaeva G.Zh., Kydyrova Z.Sh., Baineeva P.T., Abishov N.U. Priorities of social support of the population of republic of Kazakhstan in the conditions of modernization...

Rakhimova S. A., Turgumbekova M. M. Programs of government support for sme in the republic of Kazakhstan and measures to enhance their efficiency.

Rudenko Ye.I. Misperception between the states of Central and South Asia as a 'Soft power' and information security issue...

Tokhtabayeva Sh. Zh. Treasure-chest.

Utepkalieva K.M., Sabirova R.K., Kenbaeva G.U.Development of public private partnership approach in oil and gas of Kazakhstan.

Mynbayeva D.E. Concept of organization of management accounting in b

Sultanova G. S. Pedagogical aspects of formation of professional competence of the bachelor - economist of the new formation.

Shavakhmetova A.A. On the training of teaching staff for inclusive education under the conditions of higher education institution. 


\section{PUBLICATION ETHICS AND PUBLICATION MALPRACTICE IN THE JOURNALS OF THE NATIONAL ACADEMY OF SCIENCES OF THE REPUBLIC OF KAZAKHSTAN}

For information on Ethics in publishing and Ethical guidelines for journal publication see http://www.elsevier.com/publishingethics and http://www.elsevier.com/journal-authors/ethics.

Submission of an article to the National Academy of Sciences of the Republic of Kazakhstan implies that the work described has not been published previously (except in the form of an abstract or as part of a published lecture or academic thesis or as an electronic preprint, see $\mathrm{http} / / / \mathrm{www} . e l s e v i e r . c o m / p o s t i n g p o l i c y)$, that it is not under consideration for publication elsewhere, that its publication is approved by all authors and tacitly or explicitly by the responsible authorities where the work was carried out, and that, if accepted, it will not be published elsewhere in the same form, in English or in any other language, including electronically without the written consent of the copyrightholder. In particular, translations into English of papers already published in another language are not accepted.

No other forms of scientific misconduct are allowed, such as plagiarism, falsification, fraudulent data, incorrect interpretation of other works, incorrect citations, etc. The National Academy of Sciences of the Republic of Kazakhstan follows the Code of Conduct of the Committee on Publication Ethics (COPE), and follows the COPE Flowcharts for Resolving Cases of Suspected Misconduct (http://publicationethics.org/files/u2/New_Code.pdf). To verify originality, your article may be checked by the originality detection service Cross Check http://www.elsevier.com/editors/plagdetect.

The authors are obliged to participate in peer review process and be ready to provide corrections, clarifications, retractions and apologies when needed. All authors of a paper should have significantly contributed to the research.

The reviewers should provide objective judgments and should point out relevant published works which are not yet cited. Reviewed articles should be treated confidentially. The reviewers will be chosen in such a way that there is no conflict of interests with respect to the research, the authors and/or the research funders.

The editors have complete responsibility and authority to reject or accept a paper, and they will only accept a paper when reasonably certain. They will preserve anonymity of reviewers and promote publication of corrections, clarifications, retractions and apologies when needed. The acceptance of a paper automatically implies the copyright transfer to the National Academy of sciences of the Republic of Kazakhstan.

The Editorial Board of the National Academy of sciences of the Republic of Kazakhstan will monitor and safeguard publishing ethics. 
Правила оформления статьи для публикации в журнале смотреть на сайте:

\section{www:nauka-nanrk.kz}

\section{social-human.kz}

Редакторы М.С. Ахметова, Т.А. Апендиев, Д.С. Аленов

Верстка на компьютере А.М. Кульгинбаевой

Подписано в печать 08.12.2018

Формат 60x881/8. Бумага офсетная. Печать - ризограф.

17,7 п.л. Тираж 500. Заказ 6.

Национальная академия наук $Р К$

050010, Алматы, ул. Шевченко, 28, т. 272-13-18, 272-13-19 